Copyright (C) 2021 by Cherkas Global University

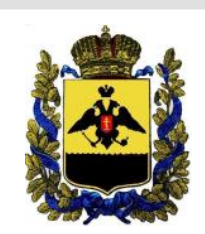

Published in the USA

Bylye Gody

Has been issued since 2006.

E-ISSN: $2310-0028$

2021. 16(4): 1981-1995

DOI: $10.13187 /$ bg.2021.4.1981

Journal homepage:

https://bg.cherkasgu.press

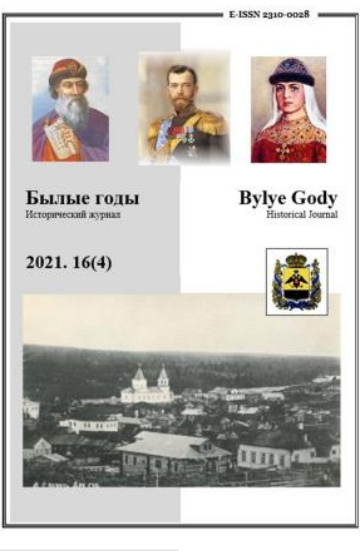

\title{
Unknown Project of the Reform of Governance of the Russian Cossack Hosts: Report by General N.A. Maslakovets to A.N. Kuropatkin in 1900
}

\author{
Artyom Yu. Peretyatko a , b, * \\ ${ }^{a}$ Cherkas Global University, Washington, USA \\ b Volgograd State University, Volgograd, Russian Federation
}

\begin{abstract}
The article is devoted to the analysis of the document, which was not previously involved in scientific circulation, «Doklad sostoyashchego v rasporyazhenii voennogo ministra General'nogo shtaba generalleitenanta Maslakovtsa po voprosu o detsentralizatsii del Glavnogo Upravleniya Kazach'ikh voisk». Contrary to its name, this text proposed a complete restructuring of the administrative structure of the Russian Cossacks, with the granting of broad economic autonomy. It was prepared in 1900, when the War Ministry of the Russian Empire was concerned about the impoverishment of the Cossacks, especially in the Don Host. An authoritative government expert on Cossack issues, the former Orenburg ataman N.A. Maslakovets, said that the administrative structure of the Cossack troops should also contribute to the achievement of Cossack welfare. He proposed giving to the Host's administrations broad economic autonomy and introducing elected delegates from the stanitsas to their composition, so that they defend the economic interests of the Cossacks. The most curious conclusion from the analysis of the text is that many ideas of N.A. Maslakovets coincided with the ideas of the Don opposition figures. The general, like them, believed that the well-being of the Cossacks with their complete submission to the imperial administration was impossible.

Keywords: public thought about the Cossacks, self-government of the Cossack Hosts, the War Ministry, N.A. Maslakovets.

\section{1. Введение}

Рубеж XIX-XX вв. для казачьих войск ознаменовался последней попыткой системных реформ, предпринятой до гибели Российской империи. Эта попытка так и осталась нереализованной, а ее история до сих пор не написана. Тем не менее по архивным документам нам удалось восстановить общий ход событий. В 1898 г. донские дворяне подали Николаю II ходатайство о необходимости борьбы с обеднением простых казаков (ГАРО. Ф. 410. Оп. 1. Д. 682. Л. 3-5). Ходатайство было удовлетворено, и император постановил создать в Новочеркасске особую выборную комиссию под председательством генерал-лейтенанта Н.А. Маслаковца, призванную выяснить причины обеднения казачества и разработать меры для борьбы с ним (ГАРО. Ф. 410. Оп. 1. Д. 682. Л. 6-6об.). Казачьими проблемами заинтересовался лично военный министр А.Н. Куропаткин, к началу следующего, 1899 г., подготовивший список мер, реализация которых могла бы быть полезна казачьим войскам (РГВИА. Ф. 330. Оп. 61. Д. 2109. Л. 93-98). Вот только большая часть этих мер носила чисто декларативный характер, и конкретные формы их реализации оставались не ясны (например, военный министр призывал безо всякой детализации «окончить поземельные вопросы» на казачьих территориях и научить казаков «более обширной сельскохозяйственной деятельности» (РГВИА. Ф. 330. Оп. 61. Д. 2109. Л. 97). С другой стороны, на тот же 1899 г. приходится деятельность комиссии Н.А. Маслаковца, подготовившей более проработанный и системный, но при этом никак не
\end{abstract}

${ }^{*}$ Corresponding author

E-mail addresses: ArtPeretatko@yandex.ru (A.Yu. Peretyatko) 
связанный с предложениями А.Н. Куропаткина проект реформ в казачьих войсках (Маслаковец, 1899). Не вдаваясь в детали этого проекта, еще ждущего своего исследователя, отметим только, что его реализацию крайне затрудняла финансовая сторона вопроса: члены комиссии утверждали, что предложенные ими реформы сократят расходы казаков более чем на 5 ооо ооо руб., однако за счет роста государственных расходов почти на 1500 ооо руб. (Маслаковец, 1899: 118). Между тем Министерство финансов выступало против дальнейшего увеличения расходов на казачьи войска, сравнивая его с «пополнением недочетов в благосостоянии казаков остальным населением Империи» (ОР РНБ. Ф. 1055. Ед. хр. 59. Л. 4). К 1900 г. А.Н. Куропаткин сумел добиться увеличения финансирования Войска Донского на 538 ооо руб. и принял решение отбыть на Дон, чтобы «лично самому ознакомиться на месте с условиями быта донского казака» и «тем самым уяснить большую или менышую степени важности и неотложности тех или иных из целого ряда намеченных означенной комиссией <Н.А. Маслаковца> мероприятий» (РГИА. Ф. 1263. Оп. 4. Д. 48. Л. 4). И по итогам поездки военный министр пришел к выводу, что «угрожающего на Дону еще не так много» и в казачьих войсках можно ограничиться частными реформами (РГИА. Ф. 1263. ОП. 4. 1901 г. Д. 48. Л. 510б.).

Несмотря на такой скромный результат, первоначально подвергнуть изменениям планировалось многие стороны казачьей жизни, в том числе и взаимоотношения между местными властями и Военным министерством. Инициативу в этом отношении проявил сам А.Н. Куропаткин, отмечавший «сложность центральной организации <Главного Управления Казачьих войск (ГУКВ)>, по 10 лет тянущей дела», и то, что «военный министр завален непосильной работой» (РГВИА. Ф. 330. Оп. 61. Д. 2109. Л. 96-96об.). А в 1900 г. вернувшийся с Дона Н.А. Маслаковец представил свои соображения по данному вопросу. Вот только фактически подготовленный им в итоге документ, «Доклад состоящего в распоряжении военного министра Генерального штаба генерал-лейтенанта Маслаковца по вопросу о децентрализации дел Главного Управления Казачьих войск», был посвящен далеко не указанной в заглавии теме (ОР РНБ. Ф. 1055. Ед. хр. 7). Н.А. Маслаковец, почти сорок лет прослуживший в гражданских администрациях казачьих войск и ставший к концу 1890 гг. главным экспертом Военного министерства по казачьим вопросам, представил аналитическую записку, посвященную существующей концепции управления казачьими войсками, причинам появления этой концепции, ее критике и, главное, необходимости замены этой концепции на принципиально другую, предполагающую значительно большую автономию войсковых правлений, их частичную демилитаризацию и расширение выборного элемента в местных казачьих администрациях. На наш взгляд, составленный Н.А. Маслаковцем доклад более интересен вне контекста его появления, не в связи с вопросом о децентрализации ГУКВ, но в связи с общим кризисом управления российского казачества в конце XIX - начале XX вв. Подчеркнем, что данный текст принадлежал высокопоставленному военном чиновнику, неоднократно служившему посредником между Военным министерством и населением казачьих войск (помимо его председательства в упомянутой выше комиссии, можно отметить осмотр Н.А. Маслаковцем Забайкальского казачьего войска (Маслаковец, 1903). Тем не менее Н.А. Маслаковец признавал необходимость срочных реформ казачьих администраций, а его конкретные предложения во многом перекликались с идеями донских оппозиционных деятелей. Но при этом старый генерал хотел совместить традиционную военную администрацию казачьих войск с новыми демократическими элементами, сохранить существующую систему войсковой власти, но дополнить ее в соответствии с требованиями времени. Поэтому, на наш взгляд, «Доклад состоящего в распоряжении военного министра Генерального штаба генераллейтенанта Маслаковца по вопросу о децентрализации дел Главного Управления Казачьих войск», до сих пор не вовлеченный в научный оборот, заслуживает отдельного внимания историков, как крайне неортодоксальное предложение по реформе российского казачества начала ХХ в.

Но, прежде чем начинать анализ доклада, нужно отметить некоторые особенности личности и служебного положения Н.А. Маслаковца в 1900 г., без которых восприятие его текста будет неполным. К этому времени генералу оставалось всего несколько лет до семидесятилетия (он родился в 1833 г. (Григорович, 1911: 262), и, возможно, в некоторых областях его воззрения отличались определенной старомодностью. В частности, в другом своем докладе он заявлял, что научный труд по любой проблеме должен «представлять описываемые события в глубокой связи между собой, так же и по отношению их к современным явлениям, в связи с соседними с описываемою страною областями и целым государством» (ОР РНБ. Ф. 1055. Ед. хр. 4. Л. 4-4об.). Подобный системный подход был характерен для первых опубликованных исследований казачьих войск, выходивших в 1860-1880 гг. В частности, Войско Донское в это время было отражено в нескольких историко-статистических описаниях, характеризующих все стороны жизни края, от климата до религии, от народонаселения до особенностей казачьей службы (Краснов, 1863; Краснов, 1870; Номикосов, 1884). С другой стороны, системность и научность были характерны для всего Военного министерства в 1860-1870 гг., при Д.А. Милютине, когда отмечалась «внутренняя связь, которая царила между всеми, даже самыми мелкими, мероприятиями» по военному ведомству Российской империи (Военная энциклопедия, 1914: 295). А Н.А. Маслаковец как личность сформировался именно в то время. В 1860 гг. он пытался создать историко-статистические описания Оренбургского казачьего войска, содержавшие призывы к конкретным реформам, но оставшиеся в рукописях (ОР РНБ. Ф. 1055. Ед. хр. 98-100). В 1870 гг. им 
был опубликован двухтомник о донских калмыках, отличающийся, по мнению современных ученых, комплексностью при описании различных сторон жизни этой группы населения (Ряжев, Сангаджиева, 2018: 65). Для нас же особенно важно, что данный двухтомник появился вследствие подготовки к реформам калмыцких кочевий, для проведения которых, как считал Н.А. Маслаковец, было необходимо «подробное исследование страны с ее населением как в физическом, так и в этнографическом отношениях» (Маслаковец, 1872: I). Верность системному и научному подходам старый генерал сохранил до конца жизни, и в своих докладах по Военному министерству он пытался в первую очередь вырабатывать некую общую концепцию, исходя из которой уже и озвучивать конкретные предложения (ОР РНБ. Ф. 1055. Ед. хр. 4). Соответственно, если А.Н. Куропаткин и начальник ГУКВ П.О. Щербов-Нефедович считали возможным децентрализовать дела по управлению российским казачеством путем простого сокращения переписки, то Н.А. Маслаковец находил подобный шаг полумерой и смотрел глубже. Огромный опыт генерала свидетельствовал, что порочна сама концепция существущей системы управления казачеством, и без радикального пересмотра этой концепции децентрализация казачьих войск будет затруднена.

Нужно учитывать и то, что у Н.А. Маслаковца выработались достаточно своеобразные политические взгляды. В молодости он сочувствовал либеральным идеям и высказывался за «движение вперед по пути европейской цивилизации» (ОР РНБ. Ф. 1055. Ед. хр. 99. Л. 30). Однако опыт реформ казачьих войск в 1860 гг. убедил будущего генерала в том, что преобразования, основанные на чужом опыте, могут привести к совершенно непредсказуемым и даже катастрофическим последствиям (ОР РНБ. Ф. 1055. Ед. хр. 104. Л. 5-50б.). И в конце 1870 гг. Н.А. Маслаковец выступил главным противником донских земств, доказывая, что учреждения должны существовать для удовлетворения нужд края, а не наоборот. Он даже прямо адресовал земцам следующий провокационный вопрос: «Должно ли местное население, для поддержания неудавшегося существования известного рода учреждений, нести все невзгоды с ними сопряженные, или же наоборот, применение учреждений к краю должно иметь в виду единственно обеспечение населению всех доступных по местным обстоятельствам способов для достижения возможно более высокого уровня нравственного и экономического преуспеяния?» (Маслаковец, 1880: 106). Донские историки, в частности С.Г. Сватиков, считали подобную риторику прикрытием для консерватизма Н.А. Маслаковца и его нежелания делиться с земствами властными полномочиями (Сватиков, 1924: 379-381). Однако в действительности многие тексты генерала основаны на идее о том, что и преобладание военной администрации, и преобладание местной общественности равно вредны для казачьих войск. Он считал, что «для того чтобы страна развивалась, просвещалась и богатела, нужно действие двух сил - правительственной и общественной» (Маслаковец, 1880: 98). И в итоге взгляды Н.А. Маслаковца сильно отличаются от взглядов большинства его современников-казачьих деятелей: он резко расходился, например, с донскими либералами-земцами, не считая самоцелью развитие демократии и автономии казачьих территорий, но при этом генерал, в отличие от большинства правительственных чиновников, находил ограниченные автономию и демократизацию казачьих войск необходимыми для решения их насущных проблем. Сам он утверждал, что видит три предпосылки для любых успешных административных преобразований: «историческую или государственную потребность», «удовлетворение местных нужд» и «прочную организацию как самих обществ, так и государственных учреждений» (ОР РНБ. Ф. 1055. Ед. хр. 104. Л. 2).

Наконец, нужно учитывать, что в 1900 г., как мы показали выше, российское казачество казалось стоящим на рубеже новых системных реформ. Н.А. Маслаковец руководил комиссией, разработавшей план этих реформ, и его деятельность была воспринята благосклонно самим Николаем II: 6 декабря генерал получил в награду «украшенную бриллиантами табакерку с вензелевым изображением Высочайшего имени» (Григорович, 1911: 265). А указание высказать свои мысли по вопросу о децентрализации управления казачьими войсками он получил буквально через месяц, в январе 1900 г. (ОР РНБ. Ф. 1055. Ед. хр. 7. Л. 1). Более того, Н.А. Маслаковец был назначен председателем соответствующей комиссии, разрабатывавшей этот вопрос (ОР РНБ. Ф. 1055. Ед. хр. 7. Л. 1). Неудивительно, что в этих условиях он несколько увлекся и, очевидно, поверил в то, что станет своеобразным идеологом новых реформ казачества. Поэтому генерал счел «весьма тесной рамкой» предварительные планы работ комиссии, хотя эти планы уже были одобрены и А.Н. Куропаткиным, и атаманами казачьих войск (ОР РНБ. Ф. 1055. Ед. хр. 7. Л. 1 об.-2). Н.А. Маслаковец фактически попытался предложить идеальную, на основании его многолетнего опыта, концепцию управления казачьими войсками.

Таким образом, рассматриваемый нами текст принадлежит перу не просто крупнейшего эксперта Военного министерства рубежа XIX-XX вв. по казачьим вопросам. Генерал-лейтенант H.А. Маслаковец не только обладал огромным административным опытом, причем полученным исключительно в казачьих войсках: он еще и был склонен к системному восприятию информации и тщательной проработке реформ, а с идеологической точки зрения руководствовался практикой, а не политическими теориями. Разумеется, это не значит, что Н.А. Маслаковец не совершал ошибок, однако его мнение по казачьим вопросам как минимум заслуживает серьезного внимания. Соответственно и предлагаемая им концепция управления казачьими войсками, хотя и осталась 
невостребованной, представляет собой не только интересую, но и значимую альтернативу терявшим эффективность российским казачьим администрациям начала $\mathrm{XX}$ в. Возможно, реализация хотя бы некоторых его идей позволила бы несколько смягчить проблемы казачьих территорий в бурные 1900-1910 гг.

Нам остается констатировать, что «Доклад состоящего в распоряжении военного министра Генерального штаба генерал-лейтенанта Маслаковца по вопросу о децентрализации дел Главного Управления Казачьих войск» интересен сразу в трех отношениях. Во-первых, с точки зрения событийной истории он был создан во время доселе недостаточно изученной попытки системных реформ казачества и важен для понимания хода этой попытки. Во-вторых, с точки зрения исследования системы управления казачьими войсками заслуживает внимание описание Н.А. Маслаковцем становления этой системы и, главное, ее критика. В-третьих, Н.А. Маслаковец предложил достаточно обоснованную и совершенно оригинальную альтернативу тем предложениям преобразования казачьих войск, которые создавались общественными деятелями и государственными чиновниками в конце XIX - начале XX вв. И в своей статье мы попытаемся коснуться преимущественно последних двух аспектов интересующего нас текста.

\section{2. Материалы и методы}

Основным источником нашего исследования стал сам текст «Доклада состоящего в распоряжении военного министра Генерального штаба генерал-лейтенанта Маслаковца по вопросу о децентрализации дел Главного Управления Казачьих войск». Сопоставляя его с другими работами Н.А. Маслаковца, как опубликованными, так и хранящимися в его фонде в Отделе рукописей Российской национальной библиотеки, мы уточним некоторые идеи генерала. С другой стороны, мы сопоставим главные идеи доклада с мнениями по схожим вопросам других лиц, чтобы понять место проекта Н.А. Маслаковца в эволюции отечественной мысли о казачестве. Таким образом, нами будут использоваться преимущественно историко-сравнительный и историко-описательный методы.

\section{3. Обсуждение и результаты}

Как мы уже упоминали выше, под децентрализацией управления российским казачеством А.Н. Куропаткин и П.О. Щербов-Нефедович подразумевали исключительно сокращение переписки между ГУКВ и администрациями отдельных казачьих войск (ОР РНБ. Ф. 1055. Ед. хр. 7. Л. 2-20б.). Достичь этой цели предполагалось наиболее простым и логичным способом: руководство ГУКВ составило список вопросов, которые, по мнению сотрудников данного управления, могли бы без ущерба для дела решаться на местах (ОР РНБ. Ф. 1055. Ед. хр. 7. Л. 2). Нужно отметить, что в итоге именно этот вариант децентрализации управления российским казачеством и был реализован, и Н.А. Маслаковец признавал, что даже подобная полумера оказалась безусловно полезна и благотворна (ОР РНБ. Ф. 1055. Ед. хр. 8. Л. 1-5об.). Более того, генерал хорошо понимал, что у Военного министерства уже есть опыт подобного сокращения переписки, и сравнительно недавно была осуществлена аналогичная децентрализация управления российской армии в целом, за счет «увеличения компетенции военно-окружных управлений по выполнению ими распоряжений центральных органов Военного Министерства» (ОР РНБ. Ф. 1055. Ед. хр. 7. Л. 3). Однако в случае с казачьими войсками Н.А. Маслаковец призывал поставить целью реформы не простое уменьшение документооборота, а обеспечение «экономического благосостояния казачьего населения и тесно с ним связанного возвышения общего уровня имущественной правоспособности казаков» (ОР РНБ. Ф. 1055. Ед. хр. 7. Л. 20б.).

Подобная чисто экономическая цель административной реформы может показаться странной только в отрыве от того контекста, в котором на начало 1900 г. существовали казачьи войска. А.Н. Куропаткин еще не съездил на Дон и не заявил о преувеличенности заявлений о катастрофическом обеднении казачества. Военный министр еще оценивал экономическое положение казачьих войск так: «Войско Донское надорвано, другие близки к тому же» (РГВИА. Ф. 330. Оп. 61. Д. 2109. Л. 96об.). В числе собранных ГУКВ отзывов строевых генералов на материалы комиссии Н.А. Маслаковца содержались схожие утверждения об опасном обеднении казачества в целом и донских казаков в особенности. Например, генерал П.Г. Дукмасов «признавал имущественную несостоятельность донских казаков к отбыванию государственной службы на теперешних основаниях и считал полное истощение и вырождение их вредною государству крайностью» (РГВИА. Ф. 330. Оп. 61. Д. 2109. Л. 39об.). Если подобные высказывания принадлежали строевым военным, то казачьи общественные деятели и экономисты тем более били тревогу. Вот что сообщал на этот счет, например, донской журналист А.М. Греков: «Область наша переживает болезненный, критический фазис экономического роста - фазис, столь же, впрочем, естественный, сколько естественным должен быть переход края от особенностей всех малонаселенных и слабо колонизирующихся степных частей империи, с их царством ковыльных степей, целины и подножных кормов, к строю, при котором степи и пастбища превращаются в пашни, ковыль уступает место сначала пырею, потом пшенице и, наконец, чему-либо еще более высшему» (Греков, 1905: 143). Таким образом, в казачьих войсках намечался серьезный экономический кризис, пускай разные авторы и акцентировали внимание на 
различных его аспектах, от обеднения простых казаков до того, что этот кризис был кризисом роста, кризисом превращения скотоводческой Земли Войска Донского первой половины XIX в. в аграрную область Войска Донского начала XX в. И для сторонника системного подхода, каким был Н.А. Маслаковец, в этих условиях было логично поставить вопрос о том, насколько административное устройство казачьих войск способствовало их экономическому развитию.

Этот вопрос был поставлен Н.А. Маслаковцем еще при подготовке программы комиссии, созданной по ходатайству донских дворян. Генерал посвятил целый отдел программы вопросу об «отношении органов местного административного управления Войска Донского к делам станичного самоуправления и организации общественного станичного хозяйства» (Протоколы..., 1899: 3). Выборные члены комиссии вполне поддержали идею, согласно которой в числе причин обеднения казаков нельзя было не отметить деятельность администрации. Корреспондент Н.А. Маслаковца, А.А. Чигринцев, прямо указывал, что в озвученных комиссией докладах одной из «главных казачьих бед» объявляется «не соответствующее интересам казачьего населения местное управление» (ОР РНБ. Ф. 1055. Ед. хр. 24. Л. 6). О необходимости коренным образом пересмотреть экономическую политику донских властей писал и А.М. Греков, также ставивший им в вину недостаточное внимание к земельным и хозяйственным проблемам казаков: «Мы хорошо отдаем себе отчет в том, насколько вмешательство, вообще, государственной власти в хозяйственные распорядки населения должно быть оправдываемо лишь в самых исключительных случаях, в виду совершенно ясно и неотложно выяснившейся потребности в том. Но полагаем также, что пора для такого вмешательства настала на Дону. <...>. В области - необозримый, непочатый еще, можно сказать, край целых пустырей незаселенной и некультивируемой земли частного крупного владения, с которыми донские помещики теперь уже не прочь развязаться, но не находят приобретателей. Очевидно, земельная нужда коренного населения области могла бы, при некотором старании, быть удовлетворена средствами, так сказать, домашними, внутренними» (Греков, 1905: 144). Итак, донские общественные деятели и сам Н.А. Маслаковец осознали необходимость перестройки административного устройства казачества, направленной на то, чтобы войсковые власти реально вмешивались в местную экономику в интересах казаков, выполняли не только собственно административные и военные, но и экономические функции. Но ничего подобного предполагаемая А.Н. Куропаткиным и П.О. Щербовым-Нефедовичем реформа децентрализации управления российским казачеством не предусматривала, зато на войсковые правления механически переносился опыт совершенно иных по самой своей сущности государственных органов, военных округов.

И критику предложенной ГУКВ реформы Н.А. Маслаковец основывал именно на противопоставлении военных округов и казачьих войск. С его точки зрения, военно-окружные управления представляли собой не более чем «подчиненные Военному Министерству местные его органы, сфера деятельности коих заключается в исполнении на местах, в военных округах, распоряжений Военного Министерства по организации и довольствию военных сил в империи» (ОР РНБ. Ф. 1055. Ед. хр. 7. Л. 3). Соответственно, в интерпретации Н.А. Маслаковца децентрализация военных округов неизбежно имела очень ограниченный характер, поскольку по самой своей сути военно-окружные управления, помимо непосредственного руководства военными частями, могли претендовать только на роль «второстепенных распорядителей денежных кредитов военного ведомства, ассигнуемых в их распоряжение на основании расписаний государственного бюджета» (ОР РНБ. Ф. 1055. Ед. хр. 7. Л. 3-3об.). Что же из себя представляют казачьи войска, старый генерал не смог даже четко сформулировать, вместо этого перечисляя многообразные области их деятельности и особенности, отличающие их от военных округов. Он начинал с напоминания о том, что каждое казачье войско обладает «собственной войсковой территорией», «выгоды и угодья которой» должны служить источником войсковых доходов и обеспечивать не только существование казачьего населения, но и выход его на службу за свой счет (ОР РНБ. Ф. 1055. Ед. хр. 7. Л. 4). Более того, как отмечал Н.А. Маслаковец, положение казака можно было сравнить с положением обычного военнослужащего только во время пребывания в строю: на льготе и в запасе его боеспособность должна была обеспечиваться не государственной казной, но личными средствами, станичными суммами или казной войсковой (ОР РНБ. Ф. 1055. Ед. хр. 7. Л. 4об.). Таким образом, если военноокружные управления распоряжались государственными деньгами, то казачьи войска существовали за счет доходов со своей собственной земли, и даже выплачиваемые им государственные субсидии формально представляли собой «капитализированную доходность отошедших в казну войсковых регалий» (ОР РНБ. Ф. 1055. Ед. хр. 7. Л. 40б.). Завершал свою характеристику казачьих войск Н.А. Маслаковец указанием на то, что администрации этих войск, в отличие от военно-окружных управлений, осуществляют руководство не только «военной силой», но и «особой областью» во всех сферах ее жизни, причем в состав этой области могут входить сельские местности и города, населенные не казаками и управляемые на основании общеимперских, а не казачьих законоположений (ОР РНБ. Ф. 1055. Ед. хр. 7. Л. 5-5об.). Таким образом, Н.А. Маслаковец сформулировал очень важную мысль, не вполне осознанную руководством Военного министерства. Военные округа были только местными исполнительными органами центральной власти по военной части, к тому же полностью финансово зависимыми от государственного бюджета. Казачьи войска 
представляли собой полноценные территориальные администрации, причем, в отличие от администраций губернских, они обладали определенной финансовой автономией и должны были за счет местных ресурсов обеспечивать как финансирование местных административных органов, так и содержание льготных и запасных казачьих частей. Поэтому подходить к военным округам и казачьим войскам следовало совершенно по-разному, несмотря на то, что формально, например, атаман Донского Войска имел права и обязанности командующего военным округом (Волвенко, 2017: 173).

Исходя из этой мысли, генерал напоминал, что администрации военных округов и казачьих войск выполняют совершенно разные по сложности и объему работ задачи. Военно-окружные управления должны были только максимально эффективно реализовывать конкретные «распоряжения и планы организации и довольствия войск, вырабатываемые центральными органами Военного Министерства» (ОР РНБ. Ф. 1055. Ед. хр. 7. Л. 5об.). В противоположность этому войсковые правления часто оказывались вынуждены принимать самостоятельные решения, например «изыскивая все способы для беспрепятственного выполнения со стороны войскового населения и войсковой казны лежащих на них обязательств» (ОР РНБ. Ф. 1055. Ед. хр. 7. Л. 6). Руководством при этом для них служили лишь «общие указания закона о воинской повинности в казачьих войсках» (ОР РНБ. Ф. 1055. Ед. хр. 7. Л. 6). Особенно же Н.А. Маслаковец подчеркивал то, что в своей экономической деятельности администрациям казачьих войск надлежало не только «распоряжаться определенными по государственной смете кредитами», но еще активно заниматься «извлечением доходов из местных источников средств войсковой казны» и, главное, «принимать своевременные меры к поддержанию экономического благосостояния и нравственного преуспевания в среде местного казачьего населения» (ОР РНБ. Ф. 1055. Ед. хр. 7. Л. 6-6об.). Вот только, как резюмировал генерал, «установленные в военном ведомстве в силу закона и начальственного усмотрения» отношения между Военным министерством и администрациями казачьих войск на местах породили нездоровую ситуацию: брать на себя ответственность и эффективно регулировать местную экономику войсковые правления просто не могли (ОР РНБ. Ф. 1055. Ед. хр. 7. Л. 6об.). Непонимание в ГУКВ специфики казачьих войск и подход к ним с меркой военно-окружных управлений привели к тому, что выработалась «весьма стеснительная зависимость местных казачьих администраций от центральных органов Военного Министерства во всех случаях и сторонах хозяйственнораспорядительной деятельности в крае» (ОР РНБ. Ф. 1055. Ед. хр. 7. Л. 6об.). В другом своем докладе Н.А. Маслаковец еще более красноречиво описывал эту «стеснительную зависимость» казачьих чиновников на местах: «Для успешной сельскохозяйственной, как и всякой другой промышленной деятельности, необходимы дух инициативы и свобода действий со стороны лиц, ведающих этого рода операцией. Откуда же явиться такому благоприятному для развития местных производственных сил условию, когда такой почин в деле, требующий отступления от заранее установленных навек норм и правил, скорее может привести энергичного начинателя к ответственности по обвинению в превышении власти, чем дождаться торжества своих начинаний, выраженного в увеличении производительности самого предприятия?» (ОР РНБ. Ф. 1055. Ед. хр. 7. Л. 3 об.-4).

Именно четко и однозначно озвученная мысль о необходимости предоставления казачьим войскам широкой хозяйственной автономии и роднила Н.А. Маслаковца с донскими оппозиционными общественными деятелями. В их текстах конца XIX - начала XX вв. постоянно звучала мысль о том, что Донское Войско не может процветать под совершенно чуждой ему централизованной военной властью. Например, представлявший Войско Донское во II Государственной Думе кадет А.И. Петровский писал после Февральской революции в одном из своих памфлетов, обыгрывая название должности войскового наказного атамана: «Пора наказных благодетелей из города Санкт-Петербурга, которыми наказывали Тихий Дон за что-то и в предупреждение чего-то в течение почти двух столетий венценосные разорители великой страны, отошла в вечность; <..> в недалеком будущем старый Дон, всколыхнувшийся, сбросивший с себя ярмо наказа, свободным народным избранием поставит себе любаго ему войскового атамана» (Петровский, 1916: 40). Наиболее подробно обосновывал необходимость предоставления широкой автономии Донскому Войску уже в эмиграции социалист и донской казак С.Г. Сватиков. В своем классическом для казачьей историографии исследовании «Россия и Дон» он проводил следующую идею: «Не донское казачество виновато, не его вина в том, что великие начала равенства и свободы, вдохновлявшие его в течение веков, были искажены и нарушены в его родном краю в течение последнего века его существования» (Сватиков, 1924: 579). Любопытно, что и он критиковал Военное министерство второй половины XIX в. за непонимание сущности казачьих войск, за то, что казаков рассматривали исключительно как «служилое сословие», а не как «потомков вольных граждан Дона» (Сватиков, 1924: 340). Хотя тексты А.И. Петровского и С.Г. Сватикова были созданы уже после революции, они только завершали многолетнюю традицию публицистических и краеведческих исследований донских оппозиционеров. И, например, в 1899 г. схожие идеи высказал бывший земец А.А. Карасев, в одной из своих статей противопоставлявший атаманов былых времен из казаков, «радевших о пользах казачьей массы», современным не казачьим правителям края, «хлопочущим о расширении своей власти, об увеличении, на счет войскового капитала, своего жалования, о разных льготах в их административных трудах и проч.» (Карасев, 1899: 115-116).

$$
-1986-
$$


Однако даже из приведенных цитат видно, что, хотя Н.А. Маслаковец и был в вопросе об автономии казачьих войск ближе к донским оппозиционным деятелям, чем к другим чиновникам Военного министерства, он все же не разделял некоторых важных для этих деятелей положений. Если А.И. Петровский, С.Г. Сватиков и А.А. Карасев считали достижение донской автономии самоцелью, восстановлением попранной исторической справедливости, то для Н.А. Маслаковца эта автономия была только средством к обеспечению должной эффективности войсковых администраций. Здесь уместно вспомнить полемику генерала с донскими земцами, в ходе которой он доказывал, что учреждения существуют для удовлетворения нужд того края, в котором они введены. Как мы видим, и при рассмотрении вопроса о децентрализации управления российским казачеством генерал продолжал придерживаться подобного инструменталистского подхода и предлагал реформировать администрации казачьих войск, исходя из наиболее актуальных для них задач, а не абстрактных либеральных («великих начал равенства и свободы») или консервативных идей (подобные идеи, например, высказывал главноначальствующий на Кавказе А.М. Дондуков-Корсаков, который считал остро необходимым «устранить разлагающее влияние на казачьи общины посторонних элементов, могущих внести заразу социалистических тенденций в патриархальный строй казачьей жизни» (РГИА. Ф. 560. Оп. 41. Д. 147. Л. 13об.).

И именно в силу инструменталистского подхода Н.А. Маслаковец достаточно оригинально оценивал рост централизации управления казачьими войсками в XIX в. Естественно, что другие сторонники казачьей автономии считали данный процесс ошибкой и даже полноценной трагедией. Характерна уже риторика С.Г. Сватикова о «закрепощенном государством» казачестве (Сватиков, 1924: 342). Н.А. Маслаковец, напротив, считал, что в исторической перспективе усиление контроля Военного министерства над войсковыми правлениями было необходимо. Он считал, что в 18о31897 гг. в казачьих войсках происходило «собирание земель в государство», переход некогда независимых органов местной власти «под ведение органов государственного управления» (ОР РНБ. Ф. 1055. Ед. хр. 7. Л. 7). И именно за эти годы была проделана огромная «законодательноорганизационная» работа, благодаря которой для казачьих областей Российской империи было выработано полноценное законодательство «по всем сторонам административной, хозяйственнобытовой и военно-служебной деятельности» (ОР РНБ. Ф. 1055. Ед. хр. 7. Л. 7-7об.). Нужно сказать, что подобная сдержанно-позитивная оценка законодательной деятельности Военного министерства в казачьих областях была характерна для ряда донских авторов старшего поколения, современников Н.А. Маслаковца. Так, Н.И. Краснов в первом опубликованном историко-статистическом описании Земли Войска Донского так оценивал результаты введения «Положения об управлении Донского войска» от 1835 г.: «Положение привело в порядок все отрасли донского управления и хозяйства, укрепило судебную и административную власть во всех инстанциях и достигло главнейшей своей цели: централизации и порядка» (Краснов, 1863: 64). Любопытно, что сам Н.А. Маслаковец считал, что наиболее активно создание особого казачьего законодательства началось только с 1860 гг. (ОР РНБ. Ф. 1055. Ед. хр. 7. Л. 7). Подобное утверждение может показаться странным («Положения» об управлении большинством казачьих войск были введены еще при Николае I), но оно основывалось на личном опыте Н.А. Маслаковца, в 1860 гг. служившего в трех казачьих войсках - Оренбургском, Уральском и Донском. И действительно, многие иногородние чиновники отмечали, что де-факто до эпохи Великих реформ на территории казачьих войск жизнь регулировалась скорее обычным правом, чем законом. «К войсковой собственности казаки относились так, что они все считали своим достоянием даже войсковую казну, на которую простирали свое право самым незатейливым образом и приемами. Но всему этому был положен конец во время управления военным министерством генерал-адъютантом графом Милютиным», - сообщал на этот счет, например, В.Д. Новицкий, служивший чиновником для особых поручений при донском атамане М.И. Черткове (Новицкий, 1991: 52-53). Неудивительно, что авторы старшего поколения, помнившие времена, когда в казачьих войсках царил произвол местного начальства, признавали важность проделанной Военным министерством работы не только по выработке казачьего законодательства, но и по внедрению этого законодательства в жизнь.

И Н.А. Маслаковец считал, что жесткое подчинение Военному министерству всех сфер жизни в казачьих войсках, даже тех, которые «не имели по существу никакой непосредственной связи» с основной задачей этого министерства, было необходимо для «большего удобства» при формировании правового поля, в котором теперь существовало российское казачество (ОР РНБ. Ф. 1055. Ед. хр. 7. Л. 7об.). Следовательно, в рамках предлагаемого генералом инструменталистского подхода до тех пор, пока главными проблемами казачьих войск оставались проблемы юридические, а Военное министерство завершало процесс «собирания земель в государство» на казачьих территориях, экономически вредная избыточная централизация войсковых правлений была необходимым злом. Но, как отмечал генерал, 20 декабря 1897 г. был упразднен последний орган, специально представлявший интересы казачьих войск перед имперским правительством, комитет казачьих войск при ГУКВ (ОР РНБ. Ф. 1055. Ед. хр. 7. Л. 7 об.-8). И, в интерпретации Н.А. Маслаковца, этим событием собирание казачьих земель и их подчинение имперским органам окончательно завершилось (ОР РНБ. Ф. 1055. Ед. хр. 7. Л. 8). Формирование полноценного казачьего законодательства к концу 
1890 гг. тоже закончилось: все сферы жизни казаков оказались юридически регламентированы. С другой стороны, на смену юридическим проблемам на казачьих территориях пришли проблемы экономические, для разрешения которых строгая централизация была не только не полезна, но и прямо вредна. И, таким образом, из логики предложенной Н.А. Маслаковцем схемы развития отношений казачьих администраций и Военного министерства следовало, что критика донскими оппозиционными деятелями централизаторской политики имперской власти по отношению к казачеству в XIX в. основывалась на ложных предпосылках: для своего времени подобная политика была оправданна и даже необходима. Однако именно эффективность централизаторской деятельности Военного министерства с 1860 гг. привела к тому, что цели этой деятельности оказались быстро достигнуты, и продолжать ее в изменившихся условиях стало бессмысленно. И, соответственно, Н.А. Маслаковец подходил к своей главной мысли: вопрос о децентрализации казачьих войск следовало ставить не в отношении сокращения переписки, но «по существу», меняя саму структуру взаимоотношений Военного министерства и войсковых администраций (ОР РНБ. Ф. 1055. Ед. хр. 7. Л. 8). Итак, и из логики исторического развития российского казачества следовало, что систему управления казачьими войсками надлежит подчинить новой цели, а в условиях начала 1900 г. этой целью могло быть только обеспечение должного благосостояния казаков.

И Н.А. Маслаковец утверждал, что в подобных условиях необходимо подчинить реформу устройства казачьих войск трем «главным началам»:

1) Вовсе вывести из-под контроля Военного министерства «те стороны деятельности органов правительственной власти и общественного управления в городах и селениях, которые не входят в сферу компетенции министерства как органа высшей правительственной власти» (ОР РНБ. Ф. 1055. Ед. хр. 7. Л. 17).

2) Установить «нормальные отношения центральных органов Военного Министерства к органам местной администрации в казачьих войсках, предоставлением последним большей против нынешнего свободы действий в распоряжении подлежащих компетенции их дел по общественному управлению и хозяйству» (ОР РНБ. Ф. 1055. Ед. хр. 7. Л. 17-170б.).

3) Перестроить саму организацию казачьих войск, установив более тесную связь «между учреждениями общественного управления в станицах, с одной стороны, и органами окружной и войсковой администрации, с другой», и, главное, допустив «к участию в делах общественного и хозяйственного управлений в войске народный элемент, в лице выборных представителей от казачьих обществ» (ОР РНБ. Ф. 1055. Ед. хр. 7. Л. 17об.).

Таким образом, генерал предлагал провести реформу местного управления в казачьих войсках, основываясь на никогда не применявшейся по отношению к российскому казачеству концепции. Как правило, подобные реформы основывались на усилении централизаторского начала и государственного контроля; донские оппозиционеры конца XIX - начала XX вв., напротив, призывали к расширению автономии Войска Донского во всех областях, что и было реализовано на несколько лет во время Гражданской войны. Н.А. Маслаковец же предлагал совместить строгую централизацию казачьих войск в военной и политической сферах, где она была необходима для соблюдения государственных интересов, с их широкой автономией по хозяйственным и экономическим вопросам. В этом отношении очень показательно его отношение к выборному принципу в устройстве казачьих войск. Генерал считал естественным упразднение последнего органа, хотя бы на бумаге призванного отстаивать интересы казачества перед правительством, - комитета казачьих войск при ГУКВ. Позицию донских оппозиционных деятелей на этот счет хорошо описал С.Г. Сватиков, который, сначала раскритиковав назначаемость, а не выборность членов комитета казачьих войск, затем все же писал: «Депутаты от войск могли быть и бывали защитниками привилегий и интересов казачества. С уничтожением комитета военная бюрократия стала полной вершительницей судеб казачества, даже без того суррогата представительства, которое существовало в течение 32 лет (1865-1897)» (Сватиков, 1924: 437-438). Таким образом, если для некоторых донских деятелей было принципиально важно существование органа, обеспечивающего именно политическую автономию казаков, право представителей последних обсуждать проводимые в их отношении реформы, то Н.А. Маслаковец считал такой орган пережитком прошлого, эпохи, когда казачьи войска не вполне входили в Российскую империю. Но, выступая против политической автономии казачьих регионов и выборных депутатов, обеспечивающих эту автономию, Н.А. Маслаковец, вопреки позиции Военного министерства, отстаивал необходимость автономии хозяйственной и доказывал, что выборные депутаты от казаков нужны для решения не политических, а экономических проблем.

Перейдем теперь к вопросу о том, как же конкретно Н.А. Маслаковец предлагал реализовать указанные им «главные начала». Прежде всего он считал необходимым рассмотреть все «предметы ведения» Военного министерства на территории казачьих войск и разделить их на «имеющие непосредственную связь с вопросами быта местного казачьего населения и отбывания казаками воинской повинности» и посторонние, на казачий быт и военную службу влияния не оказывающие (ОР РНБ. Ф. 1055. Ед. хр. 7. Л. 8об.). Под контролем военного ведомства следовало оставить только «предметы», непосредственно влияющие на положение казаков, и притом только такие, которые 
было не выгодно передавать в ведение других министерств (ОР РНБ. Ф. 1055. Ед. хр. 7. Л. 8 об.-9). Подобная система выглядит сложной и неочевидной, и, вероятно, ее реализация породила бы множество проблем: разные чиновники могли совершенно по-разному оценивать последствия передачи отдельных вопросов по управлению казачьими войсками в гражданское ведомство. Однако логика, которой руководствовался Н.А. Маслаковец, становится понятна из других его текстов. В эпоху Великих реформ уже предпринималась попытка разделить гражданскую и военную власти в казачьих областях и в гражданском отношении подчинить казаков некоторых войск обычным общеимперским органам. И результаты этой реформы Н.А. Маслаковец, будучи оренбургским атаманом, оценивал крайне критически: «Даже по отбыванию лежащей на оренбургском войске военной повинности органы войскового управления по военной части поставлены в такое отношение к казачьим обществам, что все предъявляемые ими казакам требования в конце концов могут получить надлежащее удовлетворение лишь при содействии и непосредственном участии чинов уездной полиции» (ОР РНБ. Ф. 1055. Ед. хр. 104. Л. 5об.). Однако он же, в бытность свою помощником атамана донского, высказывался за снятие с баланса Донского Войска «расходов, имеющих общегосударственную потребность, как-то: содержание судов, гимназий, полиций, медицинской части и некоторых отделений областного правления» (Номикосов, 1884: 661). И, таким образом, и в вопросе о том, в какой степени войсковые правления должны были подчиняться гражданским органам имперской власти, Н.А. Маслаковец предлагал проявить инструменталистский подход и гибкость: оставив в целом гражданское управление казачьими территориями под контролем Военного министерства, поскольку без этого было сильно затруднено обеспечение исправного выхода казаков на службу, генерал предлагал передать отдельные органы этого управления под контроль других министерств. В результате, как он считал, произошло бы не только сокращение переписки ГУКВ по управлению казачьими войсками, но выиграло бы государственное управление в целом, поскольку целый ряд сфер жизни казачьих войск перешел бы под контроль «соответствующих», т.е., очевидно, более компетентных министерств (ОР РНБ. Ф. 1055. Ед. хр. 7. Л. 8 об.-9).

Но, пожалуй, самые интересные рассуждения Н.А. Маслаковца касались второго из указанных им «главных начал». Генерал предлагал четко разделить управление казачьими войсками на две части, «организацию войск» и «войсковое хозяйство» (ОР РНБ. Ф. 1055. Ед. хр. 7. Л. 9об.). «Организация войск» на казачьих территориях вопросов у него не вызывала, а вот «войсковое хозяйство» он предсказуемо считал совершенно неправильно поставленным. И снова Н.А. Маслаковец указывал, что Военное министерство подходит к казакам с совершенно ложной общеимперской меркой, рассматривая их как аналог «обществ государственных крестьян в других местах империи», а войска, соответственно, трактуются как «государственные имущества» (ОР РНБ. Ф. 1055. Ед. хр. 7. Л. 10об.). Между тем даже официальные акты Российской империи закрепляли войсковую территорию не за государством в целом, а за конкретным казачьим войском (ОР РНБ. Ф. 1055. Ед. хр. 7. Л. 10об.). И в результате между самим функционалом государственных и войсковых земель была огромная разница. Казенные земли, как отмечал Н.А. Маслаковец, должны были или «служить источником доходов государственного казначейства», или «удовлетворять другие государственные потребности» (ОР РНБ. Ф. 1055. Ед. хр. 7. Л. 11). Учитывая подобную общегосударственную задачу, генерал считал логичным строгое подчинение этих земель центральному органу, Министерству земледелия и государственных имуществ, и сведение органов местных до роли исполнителей воли центральной власти, подобно военно-окружным управлениям Военного министерства (ОР РНБ. Ф. 1055. Ед. хр. 7. Л. 11). В противоположность этому войсковые земли «служили исключительно к удовлетворению потребностей местного войскового населения и всего войска» (ОР РНБ. Ф. 1055. Ед. хр. 7. Л. 11об.). И Н.А. Маслаковец призывал честно признать их «общинной казачьей собственностью, ничего общего с государственными имуществами ни по цели своего назначения, ни по значению в общегосударственной экономии не имеющей» (ОР РНБ. Ф. 1055. Ед. хр. 7. Л. 110б.). А из этого следовал неожиданный и невиданный доселе в практике Военного министерства по отношению к казачеству шаг: Н.А. Маслаковец выступил с идеей признать за каждым казачьим войском «неотъемлемое право распоряжаться принадлежащими ему войсковыми землями и другим имуществом», но только до тех пор, пока «соединенные с владением войсковой территорией лежащие на казачьем войске государственные обязательства им выполняются» (ОР РНБ. Ф. 1055. Ед. хр. 7. Л. 12-120б.).

Таким образом, исходя из задач, для которых использовались войсковые земли, Н.А. Маслаковец предлагал кардинально поменять владельца этих земель. Из собственности государства они должны были стать «вотчинным частным владением» казачьего войска как «коллективной вполне правоспособной личности» (ОР РНБ. Ф. 1055. Ед. хр. 7. Л. 11-12об.). И это полностью изменило бы систему управления хозяйственной деятельностью казачьих войск: если прежде «распорядителями» этой деятельности выступали ГУКВ и Военное министерство в целом, а войсковые правления были только «исполнителями» воли центральной власти, то после реформы за ГУКВ остался бы только «общий надзор и контроль» за казачьим хозяйством на местах, а его «полноправным владельцем» стало бы «войсковое население» (ОР РНБ. Ф. 1055. Ед. хр. 7. Л. 12 об.-13). 
И здесь Н.А. Маслаковец солидаризировался даже не с донской оппозицией конца XIX - начала XX вв., но с большинством донских казаков, неоднократно выражавшим желание о том, чтобы войсковая собственность действительно стала собственностью казачьего населения соответствующего войска. Выше мы приводили цитату В.Д. Новицкого, из которой следует, что до 1860 гг., пока на Дону господствовало обычное право, к войсковой казне и относились весьма свободно, что порождало случаи коррупции и казнокрадства. И когда в начале 1860 гг. к разработке предстоящих реформ допустили представителей станиц, они выступили за решение этой проблемы путем усиления контроля над местными властями, но не со стороны центральной власти, а со стороны выборных депутатов (ГАРО. Ф. 55. Оп. 1. Д. 240. Л. 2-20б.). В частности, войсковой бюджет предлагалось составлять совместно войсковым правлением и представителями земств от казачьего сословия (ГАРО. Ф. 55. ОП. 1. Д. 240. Л. 4). В 1881 г., во время обсуждения судьбы донских земств, представители станиц вообще высказались за то, чтобы «заведование войсковыми хозяйственными делами было вручено хозяйственному выборному гражданскому управлению» (Сватиков, 1924: 383-384). И превращение хозяйственных учреждений казачьих войск из «исполнительных» органов центральной власти в «представителей войсковых интересов», как дословно формулировал Н.А. Маслаковец, безусловно было бы встречено восторгом на местах (ОР РНБ. Ф. 1055. Ед. хр. 7. Л. 12 об.-13). О такой серьезной уступке со стороны имперских властей не просили даже выборные члены комиссии, созданной по ходатайству донского дворянства (во всяком случае, в протоколах этой комиссии никаких следов подобных просьб нет).

И здесь мы переходим к одному из наиболее любопытных неочевидных сюжетов, связанных с проектом децентрализации управления российским казачеством Н.А. Маслаковца. Дело в том, что донская оппозиция и вообще значительная часть донских общественных деятелей видела в качестве органа, потенциально способного представлять интересы казачества, преимущественно земства. Снова приведем мнение А.М. Грекова на этот счет: «Только в самоуправляющемся земскообщественном организме общество может рассчитывать хотя и на медленный, но зато верный рост экономического и гражданского развития края. Сам по себе механизм исключительно административного попечения несет уже в себе задатки постоянных скачков и отступлений, ибо каждая смена личности есть в то же время и смена системы, крах ее» (Греков, 1905: 147). Во время обсуждения земского вопроса в комиссии, созданной по инициативе донского дворянства, полное одобрение встретила цитата, приведенная бывшим земцем А.А. Донецким из речей в давно распущенном донском земском собрании: «Земские учреждения служат прочным залогом будущего донской земли. Забота о народном просвещении, предупреждение и устранение народных бедствий, развитие производительных сил края и вообще улучшение хозяйственного благосостояния жителей все это неоспоримо входит в отрасль настоятельных местных нужд, и удовлетворение их предполагает такую сложную и трудную работу, которая, без участия в ней общественных сил, с успехом выполнена быть не может» (Протоколы..., 1899: 184). Комиссия выступила за восстановление земств 17 голосами против 2 (Протоколы..., 1899: 185). И другие донские комиссии, как выборные, так даже и назначаемые, неоднократно озвучивали мысль о том, что земства необходимы Дону для обеспечения представительства общественных сил перед государством (Волвенко, 2003: 41-46).

Вот только Н.А. Маслаковец считал земскую идею по отношению к казачьим областям бесперспективной. В одном из своих докладов он приводил ряд цитат российских юристов, в том числе и следующее утверждение: «Земские учреждения не введены в общую систему нашего государственного управления, а поставлены подле нее как отдельные государственно-общественные тела, не имеющие никаких органических связей с этой системой, а без этой связи они не могут продолжать развиваться здоровым образом» (Маслаковец, 1880: 96). В итоге, как констатировал генерал, на Дону земским органам изначально не было дано сфер, где они были бы полновластными хозяевами, и земцы постоянно вмешивались в области, давно и успешно администрируемые войсковыми властями, и это вмешательство предсказуемо «оказывалось несостоятельным» (Маслаковец, 1880: 5). При этом, как мы помним, генерал считал невозможным вывести гражданское управление казачьими территориями из-под юрисдикции войсковых властей в силу неразрывной связи мирной жизни казаков и их снаряжения на службу. И поэтому еще во время конфликта вокруг донских земств Н.А. Маслаковец выступал за максимально тесное сращивание последних с войсковой администрацией, включение в состав административной системы Войска Донского (Маслаковец, 1880: 96). В целом, можно констатировать, что Н.А. Маслаковец опасался антагонизма между земствами и войсковыми правлениями на казачьих территориях, поскольку первые получались защитниками интересов казачества перед последними.

И превращение самих войсковых правлений в «представителей войсковых интересов» по управлению частной войсковой собственностью решало не одну, а сразу четыре проблемы. Во-первых, резко уменьшался документооборот, поскольку ГУКВ перестало бы отвечать за войсковое имущество. Во-вторых, была бы уничтожена та «стеснительная зависимость местных казачьих администраций от центральных органов Военного Министерства» в решении хозяйственных вопросов, которая мешала экономическому развитию казачьих регионов. В-третьих, удовлетворены бы оказались давние чаяния казаков, считавших войсковую собственность своей, а не 
принадлежавшей государству. В-четвертых, наконец, отпала бы необходимость в создании казачьих земств, потенциальных рассадников недовольства и оппозиционных идей, поскольку «общественные силы» были бы привлечены в сами войсковые правления. Таким образом, огромная уступка, предлагаемая Н.А. Маслаковцем в отношении хозяйственной автономии казачьих войск, делалась в расчете на ответную уступку самих казаков. Он явно рассчитывал, что выборные представители казачества, введенные в состав войсковых органов, станут верными союзниками власти в деле поднятия казачьего благосостояния, что ослабит и оппозиционные политические настроения в казачьей среде.

Однако для того, чтобы все предложения Н.А. Маслаковца заработали, нужно было успешно реализовать третье озвученное им «главное начало» планируемых реформ казачества, укрепив связь между выборными станичными правлениями и вышестоящими органами, а главное, введя выборных депутатов в состав окружных и войсковых органов. В самом деле, разве могли быть «представителями войсковых интересов» люди, назначаемые имперской администрацией и полностью зависимые от нее? Даже если они формально были казаками, это не означало реальной готовности защищать интересы войска с угрозой своей карьере. Уже в 1860 гг. в донской публицистике с иронией писали о том, как в различные правительственные комиссии вводили «безгласных» казачьих чиновников только для того, чтобы затем свалить на них все недостатки в работе этих комиссий (ГАРО. Ф. 55. Оп. 1. Д. 34. Л. 20б.).

И здесь, нужно признать честно, Н.А. Маслаковец только обозначил пути решения проблемы. Он вполне предсказуемо предлагал разделить органы управления казачьими войсками на три категории. В первую из них должны были войти те, которые следовало передать в ведение других министерств Российской империи и устройство которых, соответственно, вовсе не должно было интересовать Военное министерство (ОР РНБ. Ф. 1055. Ед. хр. 7. Л. 13 об.-14об.). Во вторую входили бы органы собственно военного управления, как мы помним, сочтенные генералом вполне удовлетворительными (ОР РНБ. Ф. 1055. Ед. хр. 7. Л. 15). И, наконец, третью категорию составляли бы хозяйственные органы, и именно в них надлежало привлечь «народного экономиста в лице представителя казачьих станичных обществ» (ОР РНБ. Ф. 1055. Ед. хр. 7. Л. 16). Н.А. Маслаковец утверждал, что важнейшей в экономическом отношении единицей в казачьих войсках является именно станичное общество, и для соблюдения «интересов казачьего населения» между этими обществами и административными учреждениями должна существовать «прочная органическая связь» (ОР РНБ. Ф. 1055. Ед. хр. 7. Л. 15-15об.). К сожалению, он не расшифровывал этого своего высказывания, но, очевидно, речь шла о связи обратной, о возможности как для окружных властей влиять на казачьи станицы, так и для этих станиц влиять на решения чиновников. Об этом можно судить из того, что генерал считал: «прочная органическая связь» между станичными обществами и властями не установилась не только после принятия положения о станичном управлении 1870 г., но и после принятия положения о станичном управлении 1891 г., полностью подчинившего станицы чиновникам (ОР РНБ. Ф. 1055. Ед. хр. 7. Л. 15-15об.). И снова интересно обратиться к другим текстам, созданным при участии генерала. Дело в том, что после русско-турецкой войны 1877-1878 гг., когда Н.А. Маслаковец был помощником донского атамана по гражданской части, в области Войска Донского был проведен опрос всех станичных сходов, чтобы выяснить причины массового выхода на службу неисправных казаков и изыскать меры для борьбы с ним (ГАРО. Ф. 301. Оп. 10. Д. 85. Л. 1818об.). Документ, в котором расписана позиция каждой станицы области Войска Донского по данному вопросу, до сих пор хранится в Государственном архиве Ростовской области (ГАРО) (ГАРО. Ф. 301. Оп. 10. Д. 85). Любопытно, что, хотя опросы станиц происходили в разгар конфликта войсковой администрации и земств, а земцы пытались говорить от лица всего казачества, многие сходы отнеслись к земствам резко критически, связав введенные ими денежные повинности с обеднением казаков (ГАРО. Ф. 301. Оп. 10. Д. 85. Л. 29-290б.). И, очевидно, Н.А. Маслаковец считал, что для войсковых властей очень важно подобное знание о реальных настроениях в станицах и пожеланиях их жителей, без него войсковые правления не смогут стать «представителями войсковых интересов», да и достижение реального благосостояния казаков будет затруднительно.

И, чтобы иметь возможность всегда знать о настроениях простых казаков без проведения специальных опросов, Н.А. Маслаковец предлагал создать в каждом казачьем округе особое присутствие, занимающееся исключительно наблюдением за «положением дел общественного управления в станицах» и состоящее как из чиновников, так и из выборных станичных депутатов (ОР РНБ. Ф. 1055. Ед. хр. 7. Л. 16-16об.). Аналогичным образом и в общее присутствие войскового правления следовало ввести выборных депутатов, «хотя бы по одному из каждого военного округа или отдела в войске» (ОР РНБ. Ф. 1055. Ед. хр. 7. Л. 16-16об.). Генерал надеялся, что таким образом в войсковых администрациях окажется представлен «народный элемент», но при этом их общий «строго правительственный характер» не будет нарушен (ОР РНБ. Ф. 1055. Ед. хр. 7. Л. 16-16об.). Вероятно, Н.А. Маслаковец опирался на собственный позитивный опыт в комиссии, созданной по ходатайству донских дворян. В ее состав как раз были введены выборные представители от станиц большинства донских округов (кроме Таганрогского, где почти не было казачьего населения) (ОР РНБ. Ф. 1055. Ед. хр. 18. Л. 3-3об.). Несмотря на взаимную критику и даже обвинения, работа

$$
-1991-
$$


комиссии получилась очень продуктивной, а некоторые материалы, созданные в ходе работ выборными депутатами, хотя и противоречили официальной позиции Военного министерства, были оценены Н.А. Маслаковцем очень высоко. Например, доклад простого (не чиновного) дворянина П.Г. Мордвинцева об экономическим положении казаков был удостоен такой характеристики: «Обстоятельный труд статистико-экономического исследования имущественной правоспособности донского казачьего населения» (Протоколы..., 1899: 163). Позже, оценивая работу комиссии под своим председательством, генерал особенно подчеркивал «всесторонность обсуждения», обеспеченную именно тем, что к свободной дискуссии были приглашены люди совершенно разных рангов и воззрений (ОР РНБ. Ф. 1055. Ед. хр. 22. Л. 10б.). Таким образом, несмотря на необычность формы (допуск в государственные учреждения исполнительной власти специальных выборных депутатов, призванных исключительно отстаивать народные интересы), предложение Н.А. Маслаковца могло, теоретически, обеспечить давно потерянный баланс между государственной властью и потребностями общества в казачьих войсках.

Однако на практике этому, скорее всего, помешало бы то, что в поиске данного баланса не были заинтересованы многие чиновники. Так, администрация Войска Донского почти сразу же начала критику закончившей работу комиссии как раз за то, что она «ориентировалась на заявления «компетентных лиц», подразумевая под компетентными в кавычках лицами, очевидно, как раз представителей общественности (РГВИА. Ф. 330. Оп. 61. Д. 2109. Л. 81). Между тем Н.А. Маслаковец не предлагал никакого механизма, который обеспечил бы влияние выборных депутатов в органы войсковой администрации, и фактически рычаги давления на войсковых атаманов и высших войсковых чиновников оставались бы по-прежнему только у ГУКВ. Тем не менее нужно помнить, что Н.А. Маслаковец набрасывал только общую программу предстоящих реформ, и, на наш взгляд, направление (реальная децентрализация российского казачества, широкая хозяйственная автономия казачьих войск и введение в руководство этих войск выборных депутатов) было выбрано им верно. И хотя поиск оптимальных форм нового административного устройства российского казачества растянулся бы даже не на годы, а на десятилетия, сам факт начала движения в этом направлении, вероятно, способствовал бы улучшению и экономического, и социального положения в казачьих регионах.

\section{4. Заключение}

Нам остается констатировать, что «Доклад состоящего в распоряжении военного министра Генерального штаба генерал-лейтенанта Маслаковца по вопросу о децентрализации дел Главного Управления Казачьих войск» на самом деле содержал в себе совершенно оригинальный вариант дальнейшего развития российского казачества. Если для имперских чиновников конца XIX - начала XX вв., с некоторыми оговорками, была характерна централизаторская тенденция в казачьей политике, а местные оппозиционные деятели, напротив, выступали за автономию казачьих войск, то Н.А. Маслаковец, практик с огромным опытом службы на Дону и в Оренбуржье, попытался найти рациональные зерна в идеях как тех, так и других, и совместить их, казалось бы, совершенно несовместимые позиции. В этом ему помогла идея, согласно которой учреждения существовали для удовлетворения нужд края, и, соответственно, реформируя устройство казачьих войск, следовало думать не об идеологических предпочтениях и высоких идеалах, но о конкретных задачах, которые администрации этих войск решали. И, исходя из поиска максимально эффективного решения этих задач, выходило, что с военной точки зрения крайняя централизация российских казачьих войск оправданна, но с точки зрения экономической - разрушительна и вредна.

Возможно, именно этим и объяснялось то упорство, с которым в конце XIX - начале XX вв. Военное министерство и донские общественные деятели отстаивали свои точки зрения. Для российского военного ведомства, занятого в первую очередь военными задачами, было естественно исходить из принципа полного подчинения казачьих чиновников вышестоящим лицам, обеспечивающего строгую дисциплину. Для донских оппозиционеров столь же естественно было ставить во главу очевидное обеднение казачьих хозяйств и требовать ограничения военной власти, доведшей многих казаков до разорения. Но Н.А. Маслаковец показал, что в принципе между этими двумя точками зрения нет неразрешимых противоречий, и как Российская империя в целом, так и казачьи войска выиграют от некоей промежуточной, компромиссной реформы, основанной на следующих основных идеях:

1) Военное министерство должно было осознать, что оно совершенно ошибочно подходило к казакам с общеимперскими методами. Несмотря на определенные отличия в деталях, в целом центральные власти переносили на казачьи войска методы управления военными округами, на самих казаков - методы управления государственными крестьянами, а на войсковое имущество - методы управления государственным имуществом. Только осознав принципиальную разницу между обычными имперскими институтами, выполняющими потребности империи в целом, и институтами казачьими, для которых было принципиально важно удовлетворить нужды конкретного казачьего войска, можно было рассчитывать на удачную административную реформу.

2) Кроме того, Военному министерству следовало понять, что проблемы безоговорочного подчинения казаков имперскому центру и создания специального казачьего законодательства были 
успешно разрешены. Между тем крайняя централизованность казачьих войск и их подчинение исключительно Военному министерству исторически сформировались именно ради решения этих проблем. В новых условиях сохранение централизаторской тенденции, уместной и логичной в XIX в., превращалось в опасный анахронизм.

3) Новой же главной задачей существования казачьих войск должно было стать восстановление пошатнувшегося благосостояния казаков при условии продолжения несения последними военной службы. Для этого же следовало дать казачьим войскам широчайшую хозяйственную автономию, позволяющую чиновникам на местах быстро принимать сообразные местным условиям решения, и, главное, ввести в состав окружных и войсковых администраций реальных народных представителей, кровно заинтересованных в процветании станиц. При этом в военном и политическом отношениях строгая централизация казачьих войск сохранялась, а их хозяйственная автономия и введение выборных чиновников трактовались не как местное самоуправление, но как право казачьего населения распоряжаться своей коллективной собственностью.

Безусловно, конкретные предложения Н.А. Маслаковца носили слишком идеалистический характер. На практике разработанная им схема столкнулась бы со множеством проблем, от сложности в разграничении военной и хозяйственной сфер в управлении казачьими войсками до нежелания чиновников поступаться своими полномочиями ради выборных депутатов. Но именно как концепт, как идея, альтернативная не отвечавшей многим запросам времени политике Военного министерства начала XX в. в казачьих войсках, предложение Н.А. Маслаковца очень интересно. Уже одно официальное заявление о смене правительственного курса, о желании имперских властей дать казачьим войскам реальную хозяйственную автономию, сильно поменяло бы и экономическую, и политическую, и даже социальную ситуацию в казачьих регионах Российской империи.

Вот только именно поэтому идеи Н.А. Маслаковца были обречены с самого начала. Вместо совершенно частного сокращения делопроизводства генерал предлагал организовать полную перестройку российского казачества, с участием посторонних министерств и ведомств, и обреченную вызвать бурную реакцию общественности. При этом сам Н.А. Маслаковец, хотя и был признанным экспертом по казачьим вопросам, не обладал ни рычагами влияния, ни своей командой в Военном министерстве, а аппарат ГУКВ не разделял его идей. На наш взгляд, даже если бы А.Н. Куропаткина и заинтересовал «Доклад состоящего в распоряжении военного министра Генерального штаба генераллейтенанта Маслаковца по вопросу о децентрализации дел Главного Управления Казачьих войск», сам военный министр не обладал достаточной политической волей, чтобы коренным образом пересмотреть многолетнюю централизаторскую политику Военного министерства по отношению к казакам. И все же текст Н.А. Маслаковца показывает, что у казачьих войск Российской империи были определенные возможности, определенный потенциал к изменениям и адаптации к изменившемуся миру, который не был реализован из-за инерции бюрократической машины и почти полного отсутствия в руководстве военного ведомства людей, в должной мере осознававших специфику казачьих войск.

\section{Литература}

Военная энциклопедия, 1914 - Военная энциклопедия. T. XV. СПб., 1914. 320 с.

Волвенко, 2003 - Волвенко А.А. Восстановление донского земства: упущенные возможности (1882-1917) // Государственная власть и местное самоуправление. 2003. № 2. С. 41-46.

Волвенко, 2017 - Волвенко A.A. Очерки по истории донского казачества в позднеимперский период (II пол. XIX - нач. XX вв.). Ростов-на-Дону, 2017. 226 с.

ГАРО - Государственный архив Ростовской области.

Греков, 1905 - Греков А.М. Очерки экономического и хозяйственного быта населения Донской Области. Таганрог, 1905. С. 152.

Григорович, 1911 - Григорович Н.С. Памяти Н.А. Маслаковца // Труды Оренбургской ученой архивной комиссии. Вып. 23. Оренбург, 1911. С. 262-266.

Карасев, 1899 - Карасев А.А. Донские атаманы за последние полвека // Русский архив. 1899. Кн. 2. С. 106-116.

Краснов, 1863 - Краснов Н.И. Материалы для географии и статистики России, собранные офицерами Генерального штаба. Земля войска Донского. СПб., 1863. 596 с.

Краснов, 1870 - Краснов Н.И. Военное обозрение Земли Донского Войска. СПб., 1870. 288 с.

Маслаковец, 1872 - Маслаковец Н.А. Физическое и статистическое описание кочевья донских калмыков. Ч. 1. Новочеркаск, 1872. 114 с.

Маслаковец, 1880 - Маслаковец Н.A. Объяснительная записка к вопросу о применении к области войска Донского земской реформы на основаниях, соответствующих местным условиям края и бытовым особенностям главной (казачьей) массы ее населения. Новочеркасск: Областная Войска Донского типография, 1880. 124 с.

Маслаковец, 1899 - Маслаковец Н.А. О занятиях высочайше учрежденной 16-го июня 1898 года Комиссии в области войска Донского и о достигнутых ею результатах: Доклад состоящего в 
распоряжении военного министра Генерального штаба генерал-лейтенанта Маслаковца 23 авг. 1899 г. СПб., 1899. 123 с.

Маслаковец, 1903 - Маслаковец Н.A. Доклад о результатах командировки состоящего в распоряжении военного министра генерал-лейтенанта Маслаковца в 1903 году в Забайкальское казачье войско. СПб., 1903. 260 с.

Новицкий, 1991 - Новищкий В.Д. Из воспоминаний жандарма. М., 1991. 250 с.

Номикосов, 1884 - Номикосов С.Ф. Статистическое описание Области Войска Донского. Новочеркасск, 1884. 774 с.

ОР РНБ - Отдел рукописей Российской национальной библиотеки.

Петровский, 1916 - Петровский А.И. Опись войсковым, наказным и войсковым наказным атаманам, в разное время в города Черкасск, а затем Новочеркасск для управления Областью войска Донского от высшего начальства поставленным. (1738-1916 гг.). Новочеркасск: 1916. 40 с.

Протоколы..., 1899 - Протоколы Комиссии по исследованию нужд казачьего населения Донской области. Б.м., 1899. 289 с.

РГВИА - Российский государственный военно-исторический архив.

РГИА - Российский государственный исторический архив.

Ряжев, Сангаджиева, 2018 - Ряжев А.C., Сангаджиева E.B. Н.А. Маслаковец о хозяйстве донских калмыков // Монголоведение (Монгол судлал). 2018. № 14. С. 63-76.

Сватиков, 1924 - Сватиков С.Г. Россия и Дон (1549-1917 гг.). Белград, 1924. 592 с.

\section{References}

GARO - Gosudarstvennyi arkhiv Rostovskoi oblasti [State archive of the Rostov region].

Grekov, 1905 - Grekov, A.M. (1905). Ocherki ekonomicheskogo i khozyaistvennogo byta naseleniya Donskoi Oblasti [Essays about the economic and economic life of the population of the Don Region]. Taganrog. P. 152. [in Russian]

Grigorovich, 1911 - Grigorovich, N.S. (1911). Pamyati N. A. Maslakovtsa [In Memory of N.A. Maslakovets]. Trudy Orenburgskoi uchenoi arkhivnoi komissii. Issue 23. Orenburg, 1911. Pp. $262-266$. [in Russian]

Karasev, 1899 - Karasev, A.A. (1899). Donskie atamany za poslednie polveka [Don ataman over the past half-century]. Russkii arkhiv. 5: 106-116. [in Russian]

Krasnov, 1863 - Krasnov, N.I. (1863). Materialy dlja geografii i statistiki Rossii, sobrannye oficerami General'nogo shtaba. Zemlja vojska Donskogo [Materials for geography and statistics of Russia collected by officers of the General staff. Don Host Oblast]. SPb. P. 596. [in Russian]

Krasnov, 1870 - Krasnov, N.I. (1870). Voennoe obozrenie Zemli Donskogo Voiska [Military review of the Don Host Oblast]. SPb. P. 290. [in Russian]

Maslakovets, 1872 - Maslakovets, N.A. (1872). Fizicheskoe i statisticheskoe opisanie kochev'ya donskikh kalmykov [Physical and statistical description of the pastures of the Don Kalmyks]. Part 1. Novocherkask. P. 114. [in Russian]

Maslakovets, 1880 - Maslakovets, N.A. (1880). Ob"yasnitel'naya zapiska k voprosu o primenenii $\mathrm{k}$ oblasti voiska Donskogo zemskoi reformy na osnovaniyakh, sootvetstvuyushchikh mestnym usloviyam kraya i bytovym osobennostyam glavnoi (kazach'ei) massy ee naseleniya [Explanatory Note about the Question of the Application of the Reform of Zemstvo to the Don Host Oblast on the Grounds Corresponding to the Local Conditions of the Region and the Everyday Peculiarities of the Main (Cossack) Mass of its Population]. Novocherkassk. P. 124. [in Russian]

Maslakovets, 1899 - Maslakovets, N.A. (1899). O zanyatiyakh vysochaishe uchrezhdennoi 16-go iyunya 1898 goda Komissii v oblasti voiska Donskogo i o dostignutykh eyu rezul'tatakh: Doklad sostoyashchego v rasporyazhenii voennogo ministra General'nogo shtaba general-leitenanta Maslakovtsa 23 avg. 1899 g. [About the activity of the Commission in Don Cossack Hosts which was supreme approved on June 161898 and about its results: Report of the Lieutenant-General of the General Staff Maslakovets, which is the order of the War Minister. Aug. 23 1899]. SPb. P. 123. [in Russian]

Maslakovets, 1903 - Maslakovets, N.A. (1903). Doklad o rezul'tatakh komandirovki sostoyashchego v rasporyazhenii voennogo ministra general-leitenanta Maslakovtsa v 1903 godu v Zabaikal'skoe kazach'e voisko [Report about the results of the trip of Lieutenant-General Maslakovets, who was at the disposal of the Minister of War, to the Transbaikal Cossack Host in 1903]. SPb. P. 260. [in Russian]

Nomikosov, 1884 - Nomikosov, S.F. (1884). Statisticheskoe opisanie Oblasti Voiska Donskogo [Statistical description of the Don Host Oblast]. Novocherkassk. P. 774. [in Russian]

OR RNB - Otdel rukopisei Rossiiskoi natsional'noi biblioteki [Department of manuscripts of Russian national library].

Petrovskij, 1916 - Petrovskij, A.I. (1916). Opis' vojskovym, nakaznym i vojskovym nakaznym atamanam, v raznoe vremja v goroda Cherkassk, a zatem Novocherkassk dlja upravlenija Oblast'ju vojska Donskogo ot vysshego nachal'stva postavlennym. (1738-1916 gg.). [Inventory of the vojskovye, nakaznye $\mathrm{i}$ vojskovye nakaznye atamans at different times in the city of Cherkassk and then Novocherkassk to 
management of the Don Host from higher authorities delivered. (1738-1916 gg.)]. Novocherkassk. P. 40. [in Russian]

Protokoly, 1899 - Protokoly Komissii po issledovaniyu nuzhd kazach'ego naseleniya Donskoi oblasti [Logs of the Commission for the Study of needs of the Cossack Population of the Don Region]. Without a place, 1899. P. 289. [in Russian]

RGIA - Rossiiskii gosudarstvennyi istoricheskii arkhiv [Russian state historical archive]. archive].

RGVIA - Rossiiskii gosudarstvennyi voenno-istoricheskii arkhiv [Russian state military and historical

Ryazhev, Sangadzhieva, 2018 - Ryazhev, A.S., Sangadzhieva, E.V. (2018). N.A. Maslakovets o khozyaistve donskikh kalmykov [N.A. Maslakovets about the economy of the Don Kalmyks]. Mongolovedenie (Mongol sudlal). 14: 63-76 [in Russian]

Svatikov, 1924 - Svatikov, S.G. (1924). Rossiya i Don (1549-1917 gg.) [Russia and the Don (15491917)]. Belgrade. P. 592. [in Russian]

Voennaya entsiklopediya, 1914 - Voennaya entsiklopediya. [Military Encyclopedia]. Vol. XV. SPb., 1914. P. 320. [in Russian]

Volvenko, 2003 - Volvenko, A.A. (2003). Vosstanovlenie donskogo zemstva: upushchennye vozmozhnosti (1882-1917) [Restoration of the Don zemstvo: lost opportunities (1882-1917]. Gosudarstvennaya vlast' i mestnoe samoupravlenie. 2: 41-46. [in Russian]

Volvenko, 2017 - Volvenko, A.A. (2017). Ocherki po istorii donskogo kazachestva v pozdneimperskij period (II pol. XIX - nach. XX vv.) [Essays about the history of the Don Cossacks in the late imperial period (II half XIX - beginning of XX centuries)]. Rostov-on-Don. P. 226. [in Russian]

\section{Неизвестный проект реформы управления российскими казачьими войсками: доклад генерала Н.А. Маслаковца А.Н. Куропаткину в 1900 г.}

Артем Юрьевич Перетятько а , , *

а Черкас глобальный университет, Вашингтон, США

b Волгоградский государственный университет, Волгоград, Российская Федерация

Аннотация. Статья посвящена анализу документа, прежде не вовлекавшегося в научный оборот, «Доклада состоящего в распоряжении военного министра Генерального штаба генераллейтенанта Маслаковца по вопросу о децентрализации дел Главного Управления Казачьих войск». Вопреки названию, данный текст предлагал полную перестройку административного устройства российского казачества с предоставлением ему широкой хозяйственной автономии. Он был подготовлен в 1900 г., когда Военное министерство Российской империи обеспокоилось обеднением казаков, особенно в Донском Войске. Авторитетный правительственный эксперт по казачьим вопросам, бывший оренбургский атаман Н.А. Маслаковец, заявил, что и административное устройство казачьих войск должно способствовать достижению казачьего благосостояния. Он предлагал дать войсковым правлениям широкую хозяйственную автономию и ввести в их состав выборных делегатов от станиц, чтобы они отстаивали экономические интересы казачества. Наиболее любопытным выводом из анализа текста является то, что многие идеи Н.А. Маслаковца совпадали с идеями донских оппозиционных деятелей. Генерал, подобно последним, считал, что благополучие казаков при их полном подчинении имперской администрации невозможно.

Ключевые слова: общественная мысль о казачестве, самоуправление казачьих войск, Военное министерство, Н.А. Маслаковец.

\footnotetext{
* Корреспондирующий автор

Адреса электронной почты: ArtPeretatko@yandex.ru (А.Ю. Перетятько) 